https://doi.org/10.19195/0137-1150.173.12

Data przesłania artykułu: 6.09.2019

Data akceptacji artykułu: 4.12.2019

\title{
ANTONI BORTNOWSKI
}

Uniwersytet im. A. Mickiewicza w Poznaniu, Polska

\section{Może Estera Katji Petrowskiej jako próba przezwyciężenia i oswojenia traumatycznej przeszłości}

Książka Może Estera (Vielleicht Esther, 2014) wywołała małą sensację na niemieckim rynku wydawniczym, gdy jej autorka — Katja Petrowskaja — otrzymała za nią główną Nagrodę im. Ingeborg Bachmann. Wynikało to w dużej mierze z faktu, że prestiżowe wyróżnienie uzyskała praca napisana przez pochodzącą z Kijowa rosyjskojęzyczną dziennikarkę, która świadomie zdecydowała się przedstawić swoją rodzinną historię w języku niemieckim. Książka została już przetłumaczona na kilkadziesiąt języków, ale, co ciekawe, do tej pory nie ma wśród nich rosyjskiego. W 2015 roku opublikowano polski przekład pod tytyułem Może Estera autorstwa Urszuli Poprawskiej.

Utwór jest odważną próbą zmierzenia się z historią własnej rodziny, trudną i skomplikowaną, naznaczoną przez tragiczne wydarzenia XX wieku. W książce Petrowskiej zauważalne jest dążenie do przezwyciężenia traumatycznej przeszłości przez jej akceptację i sprzeciw wobec niepamięci. „Pisanie jest nie tylko sposobem na osiągnięcie nieśmiertelności, wspomaga także pamięć. Proces pisania na czymś albo wpisywania czegoś w coś jest najstarszą i — mimo długiej historii wszystkich mediów — wciąż najbardziej wyraźną metaforą pamięci”"

Słowa Aleidy Assmann, przytoczone w pracy Justyny Tabaszewskiej, bez wątpienia mają zastosowanie do Może Estera. Książka jest też próbą odnalezienia i zdefiniowania własnej tożsamości, co w wypadku Petrowskiej nie jest zadaniem prostym. Dziennikarka i pisarka pochodzi bowiem z rodziny żydowskiej, której poprzednie generacje mieszkały w Wiedniu, Kaliszu, Warszawie, aby ostatecznie na początku XX wieku osiąść w Kijowie. Sama Petrowskaja, która ukończyła

${ }^{1}$ Cyt. za: J. Tabaszewska, Od literatury jako medium pamięci do poetyki pamięci. Kategoria pamięci kulturowej w badaniach nad literatura, „Pamiętnik Literacki” 2013, nr 4, s. 54. 
Uniwersytet w Tartu, od 1999 roku mieszka na stałe w Berlinie. Autorka podejmuje zatem wyzwanie i w praktyce realizuje to, o czym pisała Birgit Neumann:

Złożony związek pamięci i tożsamości to temat wielu dzieł literackich. Prezentując go, osiągają one taki kontur narracyjny, który w codziennej pracy pamięci ma często jakość wyłącznie przednarracyjną. Liczne, przede wszystkim współczesne, teksty ukazują, jak jednostki i grupy próbują poprzez autorefleksyjne akty pamięci znaleźć gwarantujące im ciągłość odniesienie do przeszłości, uwidaczniając przy tym nie tylko stabilizujący tożsamość potencjał pamięci, lecz także jej potencjał destabilizacyjny².

Pierwszym etapem zmierzenia się z własną pamięcią staje się w wypadku Petrowskiej uwolnienie pamięci mniejszościowych spod ideologicznego ucisku, o którym wspomina Pierre Nora, prezentując typy dekolonizacji:

I wreszcie trzeci typ dekolonizacji, rozkwitający na gruzach dwudziestowiecznych reżimów totalitarnych lub komunistycznych bądź nazistowskich, bądź po prostu dyktatorskich: dekolonizacja ideologiczna, sprzyjająca spotkaniu wyzwolonych narodów z ich pamięciami długimi, tradycyjnymi, które owe reżimy konfiskowały, niszczyły lub manipulowały ${ }^{3}$.

W tym kontekście warto zwrócić uwagę na opis kijowskiego dzieciństwa głównej bohaterki na jednym $\mathrm{z}$ typowych radzieckich blokowisk. Budynek, w którym przyszło jej dorastać, jawi się jako swego rodzaju symbol radzieckiego społeczeństwa, będącego tyglem narodów, ludzi odciętych od swojej przeszłości, od pamięci. „Większość mojego dzieciństwa w Kijowie spędziłam w nowym czternastopiętrowym budynku po lewej stronie Dniepru, w dzielnicy, która powstała po wojnie i zdawała się nie mieć przeszłości, tylko czystą przyszłość"4. W tym budynku oprócz rodziny Petrowskich mieszkała także Ukrainka, która straciła bliskich w czasie Wielkiego Głodu; Osetyńczyk wychowany przez polskich partyzantów; Żyd, który cudem przeżył Holocaust; a nawet sierota ocalona z hiszpańskiej wojny domowej. Ta mozaika paradoksalnie tworzyła harmonijną wspólnotę, która jednak tylko na pierwszy rzut oka mogła być postrzegana jako jednolita grupa radzieckich obywateli z wspólną historią i pamięcią. Po rozpadzie ZSRR społeczeństwo stanęło przed koniecznością zredefiniowania swojej tożsamości, co w przypadku takich rodzin jak Petrowscy nie było zadaniem oczywistym. Bagaż wykształconej w XX wieku tożsamości imperialnej w warunkach niepodległej Ukrainy został pozbawiony punktu odniesienia, jakim były ramy państwowe (początkowo Imperium Rosyjskiego, następnie ZSRR).

Dla Petrowskiej charakterystyczne jest identyfikowanie się z rosyjską przestrzenią kulturową przy braku jakiegokolwiek odniesienia do samej Rosji jako państwa. Narratorka wielokrotnie wspomina o swojej „,rosyjskojęzyczności”, przynależności do kultury rosyjskiej. Nawet imię prababki w tym kontekście zyskuje wymiar symboliczny:

2 B. Neumann, Literatura, pamięć, tożsamość, przeł. A. Pełka [w:] Pamięć zbiorowa i kulturowa. Wspótczesna perspektywa niemiecka, red. M. Saryusz-Wolska, Kraków 2009, s. 269.

3 P. Nora, Czas pamięci, przeł. W. Dłuski, „Res Publica Nowa” 2001, nr 7, s. 37.

${ }^{4}$ K. Petrowskaja, Może Estera, przeł. U. Poprawska, Kraków 2015, s. 36. 
Dziadek, rewolucjonista, który zmienił nie tylko swoje nazwisko, lecz w każdym radzieckim kwestionariuszu dawał też nowe nazwisko swojej matce, zależnie od wymogów czasu, pracy i swoich literackich preferencji, aż doszedł do Anny Arkadiewnej, tak nazywała się Anna Karenina, która w ten sposób stała się moją prababką ${ }^{5}$.

Odniesienia do literatury i kultury rosyjskiej są w tekście powszechne tak samo jak odwołania do języka ojczystego bohaterki. Petrowskaja, posługując się jasno określonym kodem, podkreśla znaczenie pamięci kulturowej, determinującej jej tożsamość i warunkującej „rosyjskość” bohaterki. Oprócz myśli Lwa Tołstoja pojawiają się w tekście cytaty z Iwana Turgieniewa, Michaiła Bułhakowa, Jewgienija Jewtuszenki, a także Aleksandra Puszkina czy Michaiła Lermontowa (niestety część z nich znika w polskim thumaczeniu, choć zachowane są na przykład w ukraińskim przekładzie).

Petrowskaja uczciwie konstatuje nabytą tożsamość, niewynikającą z ciągłości pokoleń, lecz będącą rezultatem czynników zewnętrznych i indywidualnych wyborów, które trwale związały jej rodzinę z rosyjskim kręgiem kulturowym. Widać to między innymi na przykładzie jej wujka:

Kiedy w 1940 roku w wieku lat szesnastu [wujek — A. B.] wystąpił w Kijowie o paszport, otrzymał dokument, w którego piątej linijce widniało Rosjanin, choć jego rodzice byli Żydami i mieli w paszportach odpowiedni wpis. $Z$ blond czupryną, niebieskimi oczyma, szerokimi ramionami i wąskimi biodrami Wil (skrótowiec od Władimir Iljicz Lenin) wyglądał rzeczywiście jak dzielny Iwan z baśni. Wskutek jakiej matematycznej operacji z dwojga Żydów powstał Rosjanin, i to nie w chwili narodzin, ale podczas wizyty w urzędzie paszportowym, pozostało tajemnicą, lecz w rezultacie Wilia, jak go nazywaliśmy, stał się pełnowartościowym Rosjaninem, pozbawionym żydowskiego balastu 6 .

Trzeźwa konstatacja realnych podstaw własnej „rosyjskości” pozwala Petrowskiej uniknąć idealizacji i mitologizacji rodzinnej przeszłości. Dzięki temu udaje się jej przezwyciężyć zjawisko narzuconej przez państwo bezrefleksyjnej tożsamości imperialnej, która często wypiera pamięć rodzinną czy narodową. Samoidentyfikacja narratorki staje się rezultatem świadomego wyboru, indywidualnej decyzji, a nie mechanicznie dziedziczoną kategorią, wpisywaną do paszportu. Pisząc o swoim ojcu, Petrowskaja konstatuje:

Młodszy brat Wila, mój ojciec Miron, urodzony osiem lat później, nosił odmienione nazwisko dziadka Meira i miał w paszporcie słowo Żyd. Ponieważ żydostwo już dla niego nie istniało, również Miron stał się Rosjaninem, obywatelem narodu czytelników. Do swojego pochodzenia odnosił się z respektem i zadumą, choć niekiedy także z pewnym zdziwieniem, co właściwie miałby mieć z nim wspólnego ${ }^{7}$.

Autorka zdaje sobie sprawę, że została częścią inkluzywnej kultury rosyjskiej, z której nie ma zamiaru rezygnować. Nie zamierza też $\mathrm{w}$ żaden sposób tłumaczyć się z tego czy tym bardziej kogokolwiek za to obwiniać.

\footnotetext{
5 Ibidem, s. 17.

6 Ibidem, s. 33.

7 Ibidem, s. 34.
} 
Przezwyciężenie traumy totalitaryzmu w Może Estera następuje przez odzyskanie przeszłości swojej rodziny, złamanie państwowego monopolu na pamięć. Petrowskaja wprost mówi o problemie dezintegracji więzi rodzinnych w ZSRR, prowadzącej do zapomnienia i pozbawienia pamięci, a w rezultacie do utraty tożsamości:

W innych czasach, poprzedzających świętowanie przy naszym długim stole, duża rodzina była przekleństwem, bo wśród krewnych mogli się znaleźć białogwardziści, sabotażyści, szlachetnie urodzeni, kułacy, żyjący za granicą, zbyt wykształceni, wrogowie ludu i ich dzieci, jak również inni podejrzani, a podejrzani byli wszyscy, dlatego rodziny cierpiały na zanik pamięci, często, żeby się ratować, co pomagało tylko rzadko, i kiedy wówczas świętowaliśmy, tacy krewni, jeśli w ogóle istnieli, byli już najczęściej zapomniani, często ukrywani przed dziećmi, i tak kurczyły się rodziny, całe ich gałęzie szły w zapomnienie ${ }^{8}$.

Zapomnienie wynika też z nieumiejętności rozmawiania, przekazywania sobie pamięci. Petrowskaja, próbując zrozumieć proces międzypokoleniowego „zapominania” na przykładzie swojej rodziny, dochodzi do wniosku, że odpowiedzialność za przerwanie transferu pamięci leży zarówno na „ojcach”, jak i na „dzieciach”. Milczenie staje się największym zagrożeniem dla pamięci. Petrowskaja mówi o tym przy okazji prezentacji sylwetki ciotki Lidy:

Przemilczała [ciotka - A. B.] wszystko, swoją wcześniejszą urodę, swoje oczytanie, [...] urodziny zmarłych, urodziny zamordowanych, które latami obchodziła, samotnie, przemilczała też inne daty, pamiętała o wszystkim i wszystkich, którzy się z nią w życiu zetknęli, przemilczała wojnę i to, co przedtem, i to, co potem, i wszystkie pociągi, i wszystkie miasta, opłakiwanie ojca, który przeżył wojnę, lecz nie wrócił do rodziny ${ }^{9}$.

\section{Dalej narratorka stawia retoryczne pytanie:}

O nic jej nie pytałam i teraz zadaję sobie pytanie, dlaczego tak zupełnie ją przeoczyłam, ją i jej życie, jakbym akceptowała od początku jej głuchoniemość z wyboru, jej rolę i służbę. Co wtedy w ogóle robiłam, kiedy mogła mi to wszystko ofiarować, na przykład przepis na EBP.KBAC, mnie i całej Eвpone? ${ }^{10}$

Próbując zmierzyć się z trudnym dziedzictwem radzieckim, Petrowskaja wyraźnie opowiada się po stronie „kultury winy”, a nie „kultury wstydu”, zgodnie z takim znaczeniem tych pojęć, jakie nadał im Jeffrey Olick w pracy The Politics of Regret. On Collective Memory and Historical Responsibility $(2007)^{11}$ :

Kiedy poznawałam kogoś z Polski, miałam zwyczaj przepraszać go najpierw za trzy rozbiory, a potem za to, że radziecka armia w 1944 roku czekała na brzegu Wisły, aż powstanie warszawskie zostanie stłumione, przepraszałam nowoczesnych europejskich Polaków, których uczyniłam więźniami swego sumienia, przepraszałam ich za Katyń i za to, co działo się w kanałach, bo o tym wiedziałam, ale nic nie mogłam uczynić, przepraszałam nawet za rok

\footnotetext{
8 Ibidem, s. 22.

9 Ibidem, s. 31.

10 Ibidem.
}

11 Różnice między oboma podejściami trafnie podsumowuje Maria Kobielska (eadem, Pamięć zbiorowa w centrum nowoczesności. Ujęcie Jeffreya K. Olicka, „Teksty Drugie” 2010, nr 6, s. 191).

Slavica Wratislaviensia 173, 2020

(C) for this edition by CNS 
1981, jakbym wtedy jako jedenastolatka powinna była ratować Solidarność. Bo winni byliśmy my. Czułam się cząstką imperium radzieckiego, mając świadomość jego osiągnięć, ale także idącego za nami krok w krok cierpienia, którego przysporzyliśmy innym ${ }^{12}$.

Przytoczony fragment świadczy także o tym, że autorka w swoich rozważaniach o pamięci i historii przyjmuje sformułowaną przez Aleidę Assmann perspektywę pamięci dialogicznej, która w przeciwieństwie do pamiętania monologicznego proponuje przekroczenie ram narodowych i obustronne uznanie także „nie swoich” ofiar, to jest empatyczne włączenie spowodowanych przez siebie cierpień drugiego narodu do własnej pamięci ${ }^{13}$. Taka postawa zostaje zamanifestowana już w pierwszych zdaniach powieści:

Wolałabym nie musieć rozpoczynać moich podróży tu, na tym odludziu wokół dworca, które wciąż jeszcze świadczy o spustoszeniu tego miasta, miasta, które zostało zbombardowane i zrujnowane w trakcie zwycięskich bitew $[\ldots]^{14}$.

Akcja Może Estera rozpoczyna się na Dworcu Głównym Berlina i wskazuje na uniwersalny, ogólnoludzki wymiar traumy drugiej wojny światowej. Wzięcie odpowiedzialności i świadome uznanie winy po raz kolejny staje się częścią strategii Petrowskiej, nakierowanej na przezwyciężenie traumatycznej przeszłości.

Takie podejście w Może Estera dotyczy także rodzinnej historii. Autorka nie idealizuje przeszłości, nie próbuje mitologizować swoich przodków i otwarcie mówi o odkrytych i niejednokrotnie przemilczanych traumach w kręgu najbliższych sobie ludzi (zdradzone żony, nieślubne i porzucone dzieci itp.). Demaskuje w ten sposób rodzinne legendy, wynikające ze skłonności do wypierania bolesnych epizodów z przeszłości. „Uwalnia” też z przeszłości postaci, o których z różnych powodów nie mówiło się $\mathrm{w}$ domu. Taka osobą był na przykład brat dziadka narratorki, który w latach trzydziestych został skazany na śmierć za zabójstwo niemieckiego ambasadora:

Jako zamachowiec pozostał nam na zawsze obcy, nie strzela się przecież do innych ludzi! Mimo swego tragicznego końca nie był ofiarą. Ponieważ był szalony, o jego odpowiedzialności nie można było mówić, i w ten sposób zamknęliśmy go w przeszłości ${ }^{15}$.

Petrowskaja poświęca krewnemu cały rozdział swojej książki, przy czym należy zauważyć, że i w tym, i w innych przypadkach nie ucieka się do osądzania, oskarżania, lecz jedynie konsekwentnie wypowiada i ukazuje znane jej fakty, odrzucając selektywne podejście do rodzinnej przeszłości. W ten sposób Petrowskaja po raz kolejny udowadnia, że w jej postrzeganiu pamięć nie służy szukaniu winnych i wymierzaniu sprawiedliwości — jest ona czynnikiem integrującym, a nie antagonizującym.

12 K. Petrowskaja, Może Estera..., s. 83-84.

13 A. Burdziej, Kultura jako pamięć. Aleidy Assmann dialog ze współczesnościa, „Litteraria Copernicana" 2014, nr 2 (14), s. 369.

14 K. Petrowskaja, Może Estera..., s. 5.

15 Ibidem, s. 135. 
Nie zmienia to jednak faktu, że należy precyzyjnie określać wydarzenia z przeszłości, aby uniknąć w ten sposób zniekształceń pamięci, nawet najbardziej bolesnej. Petrowskaja stara się nazywać rzeczy po imieniu, co, jak już wspomnieliśmy, jest elementem strategii oswojenia traumatycznej przeszłości. Jako przykład można przytoczyć historię prababci głównej bohaterki:

Anna została zamordowana w Babim Jarze, choć moi rodzice nigdy nie mówili „,zamordowana”. Mówili, że Anna leży w Babim Jarze, jakby dzięki temu leżeniu dusze Anny i moich rodziców mogły znaleźć spokój i jakby uchylone było także pytanie o sprawców ${ }^{16}$.

Poszukiwanie korzeni i informacji o przodkach nie służy bohaterce Może Estera do zrekonstruowania przeszłości, zdaje ona sobie sprawę, że pamięć służy odbudowaniu poczucia ciągłości, odnalezieniu i ukonstytuowaniu tożsamości. Petrowskaja jest tego świadoma, wyrażając już w pierwszym rozdziale wątpliwość, czy „potrzebę szukania czegoś, co zaginęło, w ogóle można nazwać celem”"17 (w ukraińskim tłumaczeniu zamiast ,zaginęło” pada słowo „zniknęło”- - зникло ${ }^{18}$, co naszym zdaniem lepiej oddaje punkt widzenia bohaterki).

Pamięć nie jest jedynie przechowywaniem dokumentalnych relacji, nie staje się tożsama $\mathrm{z}$ wiedzą o przeszłości. W rozumieniu Petrowskiej przybiera ona niejednokrotnie kształt łącznika, utrzymującego duchową więź z przodkami. Narratorka uświadamia to sobie przy próbie odczytania chaotycznie spisanych wspomnień swojej babci:

Przez wiele lat myślałam, że da się to odcyfrować, [...] aż zrozumiałam, że pisanie Rozy nie było przeznaczone do czytania, lecz żeby mieć się czego uchwycić — grubo skręcona, niedająca się rozerwać nić Ariadny ${ }^{19}$.

Petrowskaja porusza również inną stronę integrującej roli pamięci, gdyż w myśl stanowiska Olicka „nie jest wyłącznie tak, że pamiętamy [remember] jako członkowie grup [as members of groups], ale także jednocześnie konstytuujemy te grupy i tworzymy [siebie jako] ich członków [members] przez akt pamiętania [re-member-ing]"20. Zgłębianie przeszłości w utworze Petrowskiej nie tylko odbudowuje utracone więzi, ale też tworzy nowe połączenia, kształtując swego rodzaju kulturę pamiętania:

Tak jest z szukaniem, w trakcie którego trafia się na podobnie nastawionych, Bóg gugluje nasze drogi, abyśmy nie wypadli z naszych kolein, ciągle spotykam ludzi, którzy szukają tego co ja, powiedziałam, dlatego też spotkaliśmy się tutaj, a stary człowiek odrzekł, że to jest właśnie przeznaczenie ${ }^{21}$.

\footnotetext{
16 Ibidem, s. 182.

17 Ibidem, s. 9.

18 К. Петровська, Мабуть Естер, przeł. Ю. Прохасько, Чернівці 2016, s. 11.

19 K. Petrowskaja, Może Estera..., s. 57.

20 Cyt. za: M. Kobielska, Pamięć zbiorowa..., s. 182.

${ }^{21}$ K. Petrowskaja, Może Estera..., s. 9.
} 
Przyjazd Petrowskiej do Warszawy, miejsca narodzin jej babci, można interpretować w kluczu pojęć zaproponowanych przez Elżbietę Rybicką. Opis miasta powstałego z gruzów po drugiej wojnie światowej obfituje we wspomniane przez badaczkę wydrążone miejsca pamięci, „wydmuszki pamięci”22.

Dawnej Warszawy nie było. Gdzieś na końcu jednej z tych długich ulic zobaczyłam stare, na wpół zniszczone domy. Stały tam niczym otwarte książki, nagie, z wnętrzem obróconym na zewnątrz, do nieba i do ludzi, i marzły w słońcu. W znacznej części były zdemolowane, stały jeszcze tylko grzbiety i okładki, treść została wyrwana. Wewnątrz okładek ślady obcego życia, obnażona intymność 23 .

Elżbieta Rybicka w pracy Miejsce, pamięć, literatura (w perspektywie geopoetyki) przywołuje twórczość Hanny Krall, która „nie tylko przeszukuje archiwa i rozmawia ze świadkami przeszłości [...], ale w znamienny dla swego pisarstwa sposób tworzy fabularyzacje oparte na tym, co prawdopodobne"24. Katja Petrowskaja w swojej książce ucieka się do tego samego zabiegu: opierając się na świadectwach rodzinnych, kreuje obrazy przeszłości, dopełniając brakujące elementy wspomnień z pomocą wyobraźni. W ten sposób niejednokrotnie przestrzeń wydrążona z pamięci odzyskuje swą historię i przeszłość (nawet jeśli ma ona niekiedy status imaginacyjny).

Jednym z najbardziej sugestywnych obrazów-symboli jest pewien fikus, pojawiający się w rozdziale poświęconym tytułowej Esterze, prababce głównej bohaterki. Podczas ewakuacji Kijowa w 1941 roku roślina została wystawiona z ciężarówki, aby mogła się tam pomieścić rodzina dziadka Katji Petrowskiej.

W ten sposób fikus został na poboczu stromej Luterańskiej. Widzę liście tego fikusa, które teraz, w 1941 roku, drżą w rytm światowych wydarzeń. Temu fikusowi zawdzięczam swoje życie. [...] Przy tym widzę wyraźnie tego fikusa, jak porzucony stoi samotny przed domem rodzinnym mego ojca. Jego liście drżą w takt wkraczającego do miasta Wehrmachtu. Kiedy słyszę ten tupot, do którego można by gwizdać Szostakowicza, pojmuję, że mój ojciec przeżył tylko dlatego, że z ciężarówki usunięto fikusa ${ }^{25}$.

Mamy tutaj niewątpliwie do czynienia z opisaną przez Rybicką rolą utworu literackiego, który ożywia miejsca pamięci, staje się głosem polifonii pamięci ${ }^{26}$.

Podróż do miejsc, skąd pochodzą przodkowie, bohaterka traktuje jako pewnego rodzaju spłatę długu wobec poprzednich pokoleń, okazanie im szacunku przez przezwyciężenie ich anonimowości. Jednocześnie narratorka wyraźnie oddziela siebie od przeszłości, pamiętając, ale nie zlewając się z nią. Odważnie przyznaje, że tożsamość, która definiowała jej przodków, dla niej jest już zamkniętym rozdzia-

22 E. Rybicka, Miejsce, pamięć, literatura (w perspektywie geopoetyki), „Teksty Drugie” 2008, nr 1-2, s. 25-26.

${ }^{23}$ K. Petrowskaja, Może Estera..., s. 68.

24 E. Rybicka, Miejsce, pamięć, literatura..., s. 26.

25 K. Petrowskaja, Może Estera..., s. 197-198.

26 E. Rybicka, Miejsce, pamięć, literatura..., s. 31. 
łem: „Nasza żydowskość pozostała dla mnie głuchoniema, a głuchoniemota czymś żydowskim. To była moja historia, moje pochodzenie, nie byłam to jednak ja"27.

Petrowskaja wielokrotnie podkreśla, że to jednostka jest nadrzędna w kształtowaniu swojej teraźniejszości i przyszłości, ma możliwość dokonania świadomego wyboru swojej drogi, która nie musi być zdeterminowana przez przeszłość i pamięć o niej. Zjawisko to dobrze obrazuje fragment, w którym narratorka wspomina o wyborze swoim i swojego brata:

Moja babcia Roza nie rozumiałaby nas, mojego brata i mnie. On, dobiegając trzydziestki, nauczył się hebrajskiego, ja niemieckiego. On zwrócił się ku ortodoksyjnemu żydostwu, ni stąd, ni zowąd, jak uważaliśmy wszyscy, ja zakochałam się w Niemcu, co było równie dalekie od wyobrażeń Rozy o życiu. Jego hebrajski i mój niemiecki — te języki zmieniły nasze życiowe drogi, wstęp na własną odpowiedzialność. Byliśmy rodziną radziecką, rosyjską i niereligijną, rosyjskość była dumnym dziedzictwem wszystkich, którzy wiedzieli, czym jest rozpacz, w obliczu losu własnej ojczyzny, jak mówi poeta, Ty jedna jesteś moja pociecha i podpora, o wielka, potężna, rzetelna $i$ wolna mowo rosyjska ${ }^{28}$, a dzisiaj słyszę w tych słowach o radosna, o błogosławiona [słowa — i zarazem tytuł — tradycyjnej niemieckiej kolędy; przyp. thum.], określaliśmy się już nie poprzez żyjących i zmarłych krewnych i miejsca, gdzie żyli, lecz poprzez nasze języki ${ }^{29}$.

Oswojenie przeszłości odbywa się zatem w postrzeganiu Petrowskiej przez otwarte i szczere skonfrontowanie się z nią, czego rezultatem staje się emancypacja świadomej i jednocześnie pamiętającej jednostki.

Katja Petrowskaja, mieszkająca w Berlinie kijowianka, nie ulega pokusie odrzucenia pamięci o radzieckiej części tożsamości swojej rodziny. Jest świadoma, że również jej bliscy i ona sama współtworzyli radziecką rzeczywistość. Nie próbuje ukazać siebie i swoich krewnych jedynie w roli ofiar opresyjnego systemu. Opisuje na przykład entuzjazm babci Rozy wobec idei komunistycznych: „Kiedyś zaczęła śpiewać płynącą właśnie z telewizora Międzynarodówkę [...], po rosyjsku byliśmy jeszcze bardziej zjednoczeni w biedzie, ona w to wierzyła, a ja wierzę jej do dziś" 30 .

Petrowskaja odrzuca zatem wszelkie próby manipulowania przeszłością, pamięcią, podporządkowanie ich teraźniejszości.

W swoim utworze autorka często odnosi się do kwestii dziedziczenia pamięci, którą niewątpliwie można interpretować w kluczu zjawiska postpamięci:

Jej [mamy - A. B.] wojna stała się moją wojną, tak jak moje stało się również rozróżnianie tego, co przedtem, i tego, co potem, i w pewnym momencie nie potrafiłam już odróżnić jej wojny od moich wyobrażeń i pozostawić w spokoju jej wspomnień na półkach mojej pamięci ${ }^{31}$.

27 K. Petrowskaja, Może Estera..., s. 47.

28 Przytoczenie słów Mowy rosyjskiej (Русский язык, 1882) Iwana Turgieniewa jest jednym z wielu przykładów potwierdzających wspomniane wcześniej zakorzenienie autorki w rosyjskiej tradycji literacko-kulturowej.

${ }^{29}$ K. Petrowskaja, Może Estera..., s. 72.

30 Ibidem, s. 59.

31 Ibidem, s. 74. 
Wspomnienia wojenne, „odziedziczone” od matki, stają się w powieści Petrowskiej częścią bardziej kompleksowej traumatycznej pamięci o wydarzeniach drugiej wojny światowej. Szczególne miejsce zajmuje w niej tragedia w Babim Jarze. Rozmyślając nad zagładą kijowskich Żydów, Petrowskaja po raz kolejny podkreśla, że tragedia konkretnej grupy etnicznej czy społecznej ma charakter uniwersalny i dotyczy każdego człowieka. W kontekście masowej zbrodni w Babim Jarze nie można mówić o pamięci Żydów, Ukraińców czy Rosjan — to tragedia o wymiarze ogólnoludzkim:

Chciałabym tak o tym spacerze opowiedzieć, jakby możliwe było przemilczenie, że zamordowano tu również moich bliskich, jakbym mogła spacerować po tym dziwnym miejscu o nazwie Babi Jar jako człowiek abstrakcyjny, człowiek jako taki, nie tylko jako potomkini żydowskiego narodu, z którym łączy mnie już tylko poszukiwanie brakujących nagrobków. Babi Jar jest częścią mojej historii i inna nie jest mi dana, jednak nie dlatego tu jestem albo nie tylko dlatego. Coś mnie tu sprowadza, bo uważam, że nie ma obcych, gdy chodzi o ofiary. Każdy człowiek ma tu kogoś ${ }^{32}$.

Petrowskaja w rozdziałach poświęconych wydarzeniom w Babim Jarze porusza problem odrzucenia traumatycznej pamięci, wyparcia jej jako „cudzej” tragedii. „Jest dziesięć pomników [pomordowanych w Babim Jarze - A. B.], ale żadnej wspólnej pamięci, nawet w niej trwa selekcja. Czego mi brak, to słowa człowiek. Czyje są te ofiary? Czy są sierotami po naszej przegranej pamięci? Czy też wszystkie one są nasze?"33 — pyta Petrowskaja.

Innym problemem dostrzeżonym w tej części książki jest zjawisko, o którym wspomina James E. Young, poruszając kwestię procesu materializacji pamięci $\mathrm{w}$ formie pomników. Zgodnie z jego stanowiskiem nadanie pamięci formy pomnikowej rodzi poczucie częściowego zwolnienia z obowiązku pamiętania. W konsekwencji zadanie kultywowania pamięci przejmują niejako pomniki, uwalniając tym samym ludzi od brzemienia traumatycznego dziedzictwa ${ }^{34}$.

Gdy po wielu latach bohaterka Może Estera powraca do miejsca masowej zagłady z 1941 roku, stwierdza, że cały ciężar pamięci został przeniesiony na rozproszone w miejskim krajobrazie pomniki, które stały się „niewidoczne” dla współczesnych mieszkańców:

Metropolia Kijów dawno już otoczyła Babi Jar. Budka z piwem, kiosk, pomnik pomordowanych dzieci. [...] Miłośniczki sportu uprawiają jogging, chłopcy grają w piłkę nożną, mężczyźni piją na ławkach piwo, a renciści zbierają butelki — zwyczajna miejska przemiana materii. Mieszkania w tej okolicy nie są tańsze niż gdzie indziej, bo Babi Jar jest parkiem ${ }^{35}$.

Podsumowując, trzeba wskazać, że Może Estera jest odważnym aktem konfrontacji z własną przeszłością, w którym pamięć staje się narzędziem oswojenia

32 Ibidem, s. 74.

33 Ibidem, s. 177.

34 Zob. J. E. Young, Pamięć i kontrpamięć. W poszukiwaniu społecznej estetyki pomników Holokaustu, przeł. G. Dąbkowski, „Literatura na Świecie” 2004, nr 1-2, s. 267-290.

${ }^{35}$ K. Petrowskaja, Może Estera..., s. 169. 
i przezwyciężenia traumatycznych doświadczeń. Katja Petrowskaja udowadnia, że wolna i świadoma jednostka musi przyjąć przeszłość, aby właściwie określić swoje miejsce w teraźniejszości. Jednocześnie autorka Może Estera dąży do praktycznej realizacji idei pamięci dialogicznej, inkluzywnej, w której wymiar ogólnoludzki jest nadrzędny, oraz opowiada się po stronie kultury winy, zakładającej współodpowiedzialność i świadome zmierzenie się ze swoją przeszłością. Pierwszym krokiem w tym kierunku powinno być oswojenie pamięci rodzinnej, pozwalającej przejść z poziomu indywidualnego na poziom kolektywny.

\section{Bibliografia}

Burdziej A., Kultura jako pamięć. Aleidy Assmann dialog ze wspótczesnościa, „Litteraria Copernicana" 2014, nr 2 (14).

Kobielska M., Pamięć zbiorowa w centrum nowoczesności. Ujęcie Jeffreya K. Olicka, „Teksty Drugie" 2010, nr 6.

Neumann B., Literatura, pamięć, tożsamość, przeł. A. Pełka, [w:] Pamięć zbiorowa i kulturowa. Wspótczesna perspektywa niemiecka, red. M. Saryusz-Wolska, Towarzystwo Autorów i Wydawców Prac Naukowych Universitas, Kraków 2009.

Nora P., Czas pamięci, przeł. W. Dłuski, „Res Publica Nowa” 2001, nr 7.

Petrowskaja K., Może Estera, przeł. U. Poprawska, Wydawnictwo Uniwersytetu Jagiellońskiego, Kraków 2015.

Petrowśka K., Mabut' Ester, przeł. Ju. Prochaśko, Knyhy — XXI, Czerniwci 2016.

Rybicka E., Miejsce, pamięć, literatura (w perspektywie geopoetyki), „Teksty Drugie” 2008, nr 1-2. Tabaszewska J., Od literatury jako medium pamięci do poetyki pamięci. Kategoria pamięci kulturowej w badaniach nad literatura, ,Pamiętnik Literacki” 2013, nr 4.

Young J. E., Pamięć i kontrpamięć. W poszukiwaniu spotecznej estetyki pomników Holokaustu, przeł. G. Dąbkowski, „Literatura na Świecie” 2004, nr 1-2.

\section{Maybe Esther by Katya Petrovskaya as an Attempt to Overcome and Tame the Traumatic Past}

\section{Summary}

This article focuses on the specificity of looking at family past in Maybe Esther (Vielleicht Esther, 2014), Katya Petrovskaya's debut novel. Born in Kiev and living in Germany, a writer of Jewish descent tells the story of her family. By doing this, Petrovskaya tries to overcome the traumatic experience and gain her own identity. The purpose of the reflections presented in the article is to show the multidimensionality of memory and its key role in the process of forming an individual's self-consciousness. The analysis of the research material is largely based on the theoretical assumptions of J. K. Olick, A. Assmann and E. Rybitskaya (memory in the perspective of geopoetics).

Keywords: Katya Petrovskaya, Maybe Esther, cultural memory, trauma, geopoetics

Slavica Wratislaviensia 173, 2020

(C) for this edition by CNS 


\section{Кажется, Эстер Кати Петровской как попытка преодолеть и осмыслить травматическое прошлое}

Резюме

Настоящая статья посвящена особенностям взгляда на семейное прошлое в литературном дебюте Кати Петровской — в романе Кажется, Эстер (Vielleicht Esther, 2014). Pодившаяся в Киеве и проживающая в Германии писательница еврейского происхождения рассказывает историю своей семьи. С помощью творчества, Петровская пытается преодолеть травматический опыт и обрести собственную идентичность. Цель представленных в статье рассуждений - показать многомерность памяти и ее ключевую роль в процессе формирования самосознания человека. Анализ исследовательского материала в значительной степени основывается на теоретических предположениях Джеффри Олика, Алейды Ассман и Эльжбеты Рыбицкой (память в перспективе геопоэтики).

Ключевые слова: Катя Петровская, Кажется, Эстер, культурная память, травма, геопоэтика 